\title{
COMPARISON OF HEAVY METALS IN AQUATIC PLANTS ON CHARITY ISLAND, SAGINAW BAY, LAKE HURON, U.S.A., WITH PLANTS ALONG THE SHORELINE OF SAGINAW BAY ${ }^{1}$
}

\author{
George F. Estabrook, David W. Burk, Dennis R. Inman, ${ }^{2}$ \\ Peter B. Kaufman, James R. Wells, ${ }^{3}$ John D. Jones, ${ }^{4}$ \\ AND Najati GHOSHEH ${ }^{5}$
}

Division of Biological Sciences, The University of Michigan, Ann Arbor, Michigan 48109

\begin{abstract}
A B S T R A C T
The concentrations of 15 heavy metals in aquatic plants on Charity Island was compared to those in plants on the shoreline of Saginaw Bay, Lake Huron, U.S.A. Heavy metal concentrations were measured by neutron activation analysis. Charity Island was found to have significantly higher levels of nine of fifteen metals investigated. This indicates that distance from known pollution source was not the only factor affecting the heavy metal accumulation of the aquatic plants.
\end{abstract}

THE CONCENTRATIONS of 15 heavy metals in aquatic plants along the shore of Saginaw Bay and on Charity Island, Saginaw Bay was measured by neutron activation analysis. Saginaw Bay is an eutrophic embayment of Lake Huron; Charity Island is a small island which is located towards the outlet of this bay (see Fig. 1). Wells et al. (1981) specifically investigated the accumulation of heavy metals in the aquatic plants located around the shoreline of this bay, and they found that 1) aquatic plants contained heavy metals; 2) different species contained different metals in varying concentrations; 3 ) in the same species, there were different concentrations in leaves, stems, roots, and in fruits; and 4) there was no significant difference in amount of heavy metals between submerged and emergent aquatic plants.

The concentrations of 15 heavy metals in aquatic plants on Charity Island were measured by neutron activation analysis in 1982 (Table 1). The island is in a part of the bay whose water more closely resembles the water in the central part of Lake Huron, than that in the inner bay. It is greater than $15 \mathrm{~km}$ from known heavy metal sources. If there were less heavy metals in plants on the Island than in

\footnotetext{
${ }^{1}$ Received for publication 17 February 1984; revision accepted 21 November 1984.

2 Present address: Dept. of Biology, University of Toledo, Toledo, OH 43606.

${ }^{3}$ Present address: Cranbrook Institute of Science, 500 Lone Pine Rd., Bloomfield Hills, MI 48013.

4 Present address: Phoenix Memorial Laboratory, The University of Michigan, Ann Arbor, MI 48109.

${ }^{5}$ Present address: Dept. of Biology, Eastern Michigan University, Ypsilanti, MI 48197.
}

plants along the shoreline of Saginaw Bay, it would suggest that metal from these sources did not spread very far. If there were more, it would suggest that specific mechanisms of concentration, such as deposition and washing of sediment, currents, air-borne sources, or stability of the vegetation, are at work. If they were equal, it would suggest spreading rate and/ or background levels are sufficiently high that $15 \mathrm{~km}$ is virtually no distance at all in the dynamics of the system. Our results strongly suggest that which of these is the case depends on the particular heavy metal considered.

MATERIALS AND METHODS-Figure 1 illustrates the location of Charity Island in the Bay. The Island lies approximately $15 \mathrm{~km}$ north/ northwest of Caseville, Michigan. The plants were all collected from the inland pond on the island except the Chara sp., which was collected along the beach on the western shore of the Island. The plants were collected by hand and identified in the field. Preparations and handling procedures of the samples, from collection to neutron activation analysis, are given in detail in Wells et al. (1981).

The samples on Charity Island were compared with those of Wells, Kaufman and Jones (1980), Wells et al. (1981) sampled along the Saginaw Bay shore. The sites used in Wells et al. (1981) are located just off shore, from Tawas Point on the Northwest side around to Caseville on the Southeast side (see Fig. 1). Also sampled was a site located in the Huron Mountains in Marquette County in the Upper Peninsula (Fig. 2).

Samples were prepared for neutron activa- 


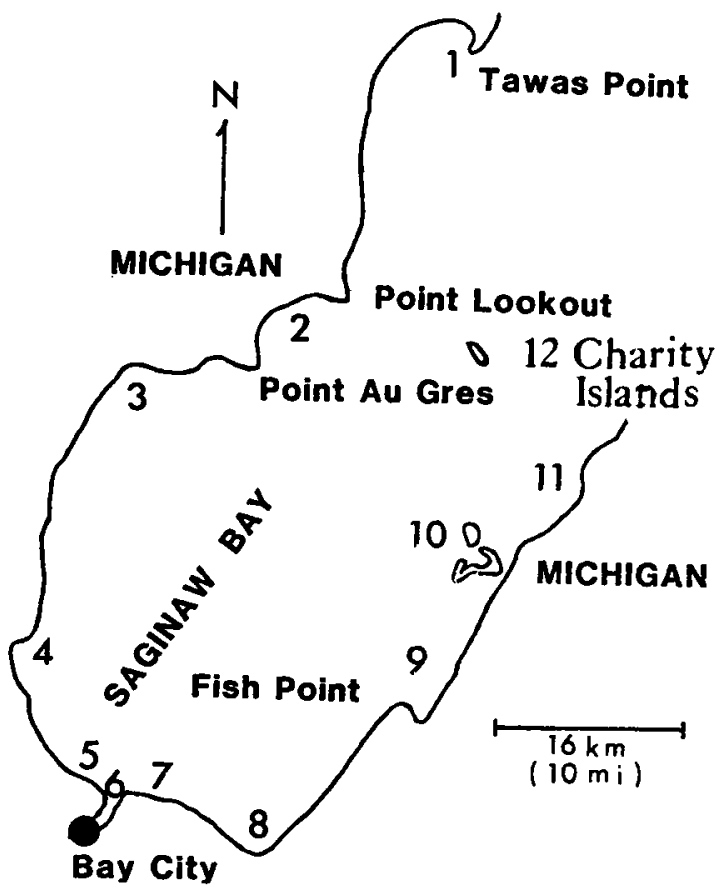

Fig. 1. Map of Saginaw Bay in Lake Huron, Michigan, indicating the location of Charity Island in the Bay.

tion analysis according to procedures cited in Wells et al. (1981). The Phoenix Lab at the University of Michigan supplied the nuclear reactor necessary for the neutron activation analysis. This analysis determines the concentration in ppm of each heavy metal in each plant sample (cf. Table 1). For each metal the variance in concentrations among the samples within each location was different among locations. The probability that all three locations (Huron Mountains, Charity Island, Saginaw Bay Shore) have the same variance is less than 0.0001 for each of the 15 metals measured. Both skewness and kurtosis have expected values of 0 for samples of normal distributions. Significances are difficult to calculate, but for a large sample such as ours (90), values above 2 are probably significant at $P<0.01$, and indicate a long tail to the right with high ends and low middle. For every metal, skewness exceeded 2 and kurtosis exceeded 4 . This is just what would be expected if most samples contained very little metal, but a few contained very much, as is the case in our study.

For these reasons, we avoided analyses of variance to test for differences among the locations, and went immediately to the nonparametric procedures of Mann and Whitney (1947), to test for significant differences in the average pooled rank order among the loca-

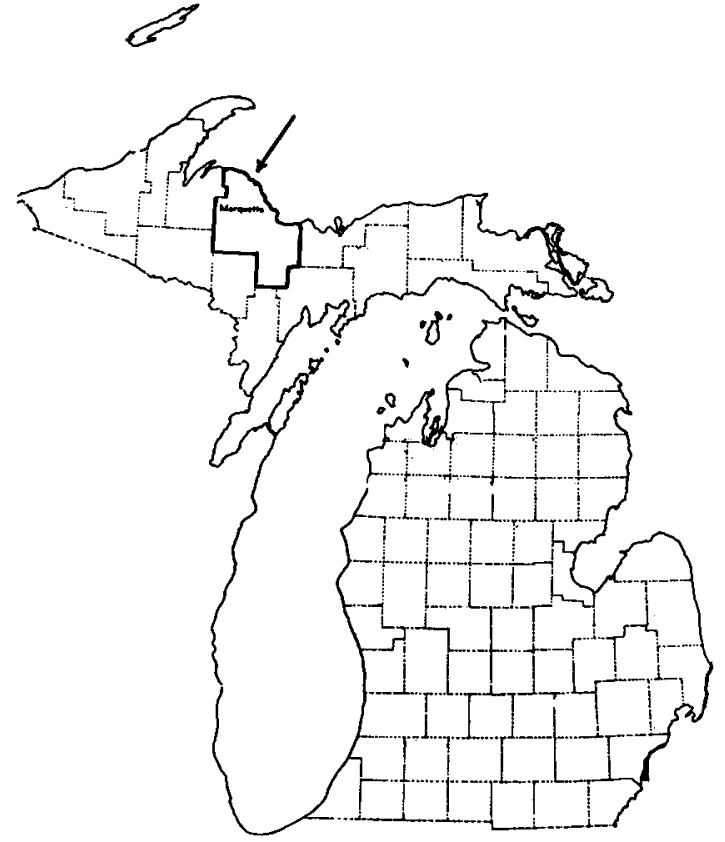

Fig. 2. Maps showing the control sites located in the Huron Mountains in Marquette County in the Upper Peninsula of Michigan.

tions, and Chi Square contingency table analysis to test for significant differences among the locations in the occurrence of the relatively fewer very large values of metal concentration, (both reviewed by Conover [1971]). Very large values were discovered by rank-ordering the observations and plotting value vs. rank order; typically, between the seventy (70) and ninety (90) percentiles, the curve began to rise markedly. Here began the appearance of "large values." In cases where the curve rose more gradually, the "large values" began rather arbitrarily in a "thin" spot near the middle of the distribution. In the two cases discussed below, this consideration is made to weaken conclusions. For each metal, its cut point, maximum value, and number of "large" values are given in Table 3 .

RESULTS-The levels of heavy metals found in the aquatic plants collected on Charity Island, along the shoreline of Saginaw Bay, and from the Huron Mountains, are presented in Tables 1 and 2 . The various trends among sites, in the heavy metal accumulation by the aquatic plants, are summarized in Table 3 .

There were only four distinct relationships among the locations; which one occurred depended on the metal, and, to a small degree, on the statistical procedure used. For each sug- 
TABLE 1. Heavy metal concentration values from each of the samples* taken on Charity Island (in parts per million)

\begin{tabular}{|c|c|c|c|c|c|c|c|c|c|c|c|c|c|c|}
\hline $\mathrm{Ag}$ & As & $\mathrm{Ba}$ & $\mathrm{Cd}$ & $\mathrm{Ce}$ & Co & $\mathrm{Cr}$ & Cs & $\mathrm{Ni}$ & $\mathrm{Rb}$ & $\mathrm{Sb}$ & $\mathrm{Se}$ & Th & $\mathbf{u}$ & $\mathrm{Zn}$ \\
\hline \multicolumn{15}{|c|}{ Glass Blank } \\
\hline 0.08 & 0.06 & 5.20 & 0.29 & 0.11 & 0.02 & 0.22 & 0.02 & 2.33 & 1.03 & 0.03 & 0.11 & 0.02 & 0.03 & 0.61 \\
\hline \multicolumn{15}{|c|}{ Potamogeton sp. Is Island } \\
\hline 0.13 & 1.32 & 461.09 & 2.01 & 0.37 & 0.11 & 1.29 & 0.15 & 7.73 & 31.62 & 0.05 & 0.34 & 0.10 & 0.22 & 19.30 \\
\hline \multicolumn{15}{|c|}{ Potamogeton sp. Is Island } \\
\hline 0.09 & 1.05 & 76.85 & 1.12 & 0.21 & 0.06 & 0.71 & 0.06 & 4.62 & 10.19 & 0.03 & 0.20 & 0.05 & 0.12 & 8.54 \\
\hline \multicolumn{15}{|c|}{ Leersia oryzoides Is Island } \\
\hline 0.18 & 0.24 & 41.11 & 1.02 & 0.21 & 0.06 & 0.49 & 0.05 & 3.89 & 11.81 & 0.04 & 0.21 & 0.05 & 0.12 & 12.05 \\
\hline \multicolumn{15}{|c|}{ Nymphaea tuberosa 1 Island } \\
\hline 0.10 & 0.33 & 30.07 & 1.84 & 0.21 & 0.10 & 0.29 & 0.04 & 3.64 & 26.12 & 0.03 & 0.18 & 0.08 & 0.20 & 10.78 \\
\hline \multicolumn{15}{|c|}{ Nymphaea tuberosa r Island } \\
\hline 0.07 & 0.30 & 21.38 & 1.34 & 0.15 & 0.08 & 0.26 & 0.03 & 2.64 & 17.57 & 0.02 & 0.13 & 0.06 & 0.14 & 10.61 \\
\hline \multicolumn{15}{|c|}{ Typha latifolia I Island } \\
\hline 0.08 & 0.34 & 18.47 & 1.34 & 0.19 & 0.06 & 0.28 & 0.02 & 2.63 & 5.07 & 0.03 & 0.17 & 0.05 & 0.14 & 5.59 \\
\hline \multicolumn{15}{|c|}{ Typha latifolia $\mathrm{r}$ Island } \\
\hline 0.09 & 0.45 & 23.53 & 1.74 & 0.17 & 0.05 & 0.78 & 0.02 & 1.96 & 12.61 & 0.02 & 0.14 & 0.07 & 0.18 & 4.03 \\
\hline \multicolumn{15}{|c|}{ Typha latifolia o Island } \\
\hline 0.20 & 0.28 & 15.69 & 0.96 & 0.52 & 0.18 & 10.89 & 0.08 & 6.33 & 13.22 & 0.03 & 0.43 & 0.11 & 0.13 & 16.22 \\
\hline \multicolumn{15}{|c|}{ Polygonum natans ls Island } \\
\hline 0.13 & 0.62 & 65.44 & 1.01 & 0.31 & 0.33 & 4.71 & 0.06 & 5.91 & 30.89 & 0.04 & 0.24 & 0.05 & 0.12 & 26.67 \\
\hline \multicolumn{15}{|c|}{ Najas flexilis w Island } \\
\hline 0.16 & 1.03 & 152.92 & 1.62 & 0.30 & 0.37 & 3.09 & 0.04 & 6.11 & 4.54 & 0.06 & 0.27 & 0.07 & 0.18 & 13.60 \\
\hline \multicolumn{15}{|c|}{ Chara sp. w Island } \\
\hline 0.21 & 4.99 & 553.08 & 0.99 & 0.32 & 0.26 & 1.05 & 0.06 & 8.62 & 2.76 & 0.05 & 0.30 & 0.06 & 0.13 & 14.83 \\
\hline \multicolumn{15}{|c|}{ Cirsium pitcheri 1 Island } \\
\hline 0.17 & 0.47 & 23.72 & 1.75 & 0.24 & 0.11 & 1.28 & 0.07 & 6.36 & 10.90 & 0.04 & 0.29 & 0.08 & 0.17 & 40.99 \\
\hline
\end{tabular}

$*$ Is = leaves and stem; $l=$ leaves; $r=$ root; $o=$ old fruits; $w=$ whole plant.

gested relationship and metal, two possible entries can be made in Table 3: the upper entry contains the results of the Chi Square contingency analysis to test the significance of the distribution of large values among the locations, and the lower entry contains the results of the Mann/Whitney analysis to test the significance of the difference of average pooled rank among the locations. One of five (5) distinct entries have been made for each metal: $* *=$ significant at 0.01 or less; $*=$ significant at between 0.05 and $0.01 ; \mathrm{T}=$ an insignificant but perfect trend with small sample size or an almost significant trend with larger sample size; $\mathrm{t}=$ trend observable but insignificant; and $-=$ distribution of this metal does not support this trend in any way.

In most cases, both rank ordering and distribution of large values suggest the same relationships among the locations for a given metal, although these differ with different metals. Saginaw Bay shore (S) plants have most of the highest values of $\mathrm{Ag}, \mathrm{Ce}$, and $\mathrm{Sb}$, and more metal by both standards for $\mathrm{Co}, \mathrm{Cr}$, and $\mathrm{Zn}$; all the rest of the metals are more abundant in samples from the Island (I). The Huron Mountain $(\mathrm{H})$ site is always not distinct from either $S$ or I. The two tests differ in the way they assess differences among locations; thus, one can reach different conclusions without evidencing contradictions. The six metals in which this occurred are discussed below:

$A g$. Only six (6) high values were encountered, all in S. Only 23 of 72 samples in S had detectable amounts, but the six large ones were among them. Every island sample had detectable amounts; most of them had higher than detectable amounts from $S$, but none of them was very high.

As. This is an example of the precariousness of small samples. The values are identical to $\mathrm{Ag}$, except one of the six large values (not the smallest large value though) falls in $I$. For $\mathrm{S}$ vs. $\mathrm{IH}$, the observed frequencies are only a few percentage points from those expected; so technically, there is not even a trend, but there is only one large value different from the pattern of $\mathrm{Ag}$. 
TABLE 2. Heavy metal concentration values from each of the samples taken along Saginaw Bay shoreline (in parts per million)

\begin{tabular}{|c|c|c|c|c|c|c|c|c|}
\hline & $\begin{array}{c}\text { Organ } \\
\text { sampled }\end{array}$ & $\begin{array}{l}\text { No. of } \\
\text { samples }\end{array}$ & $\mathrm{Ag}$ & As & $\mathrm{Ba}$ & Cd & $\mathrm{Ce}$ & $\mathrm{Co}$ \\
\hline \multicolumn{9}{|l|}{ STANDARD SAMPLES ${ }^{\mathrm{a}}$} \\
\hline Quartz blank & & 1 & 0.1 & 0.2 & $\mathrm{ND}^{\mathrm{b}}$ & ND & ND & ND \\
\hline \multicolumn{9}{|l|}{ SUBMERSED SPECIES ${ }^{c}$} \\
\hline Cladophora sp. & Wp & $4^{0}$ & ND-25.7 & $0.2-21.1$ & $69.9-158.8$ & ND & $5.6-11.1$ & $1.1-2.6$ \\
\hline $\begin{array}{l}\text { Elodea canadensis } \\
\text { Michx. }\end{array}$ & $\mathbf{L}+\mathbf{S}$ & 1 & ND & 0.4 & 47.4 & 5.7 & 0.7 & 0.4 \\
\hline $\begin{array}{l}\text { Myriophyllum } \\
\text { spicatum } \mathrm{L} \text {. }\end{array}$ & $\mathbf{L}+\mathbf{S}$ & 2 & ND & $0.6-1.6$ & $62.3-93.3$ & ND & $4.3-5.4$ & $1.1-1.2$ \\
\hline $\begin{array}{l}\text { Potamogeton cris- } \\
\text { pus L. }\end{array}$ & $\mathrm{L}+\mathrm{S}$ & 3 & $\mathrm{ND}-0.7$ & $0.5-1.6$ & ND-59.6 & ND & $1.1-2.1$ & $0.4-0.7$ \\
\hline P. pectinatus $\mathrm{L}$. & $L+S$ & 4 & $\mathrm{ND}-0.4$ & $0.8-1.7$ & ND-108.9 & ND & $2.0-5.1$ & $0.7-1.4$ \\
\hline$P$ pectinatus $\mathrm{L}$. & Fr & 2 & ND & ND-0.4 & ND & ND & $0.3-1.2$ & 0.4 \\
\hline $\begin{array}{l}P \text {. illinoensis Mo- } \\
\text { rong. }\end{array}$ & $\mathrm{L}+\mathrm{S}$ & 1 & 1.3 & 0.9 & 66.5 & ND & 3.3 & 1.0 \\
\hline $\begin{array}{l}\text { P. richardsonii } \\
\text { (Benn.) Rydb. }\end{array}$ & $\mathrm{L}+\mathrm{S}$ & 3 & $\mathrm{ND}-0.4$ & $0.4-0.7$ & $48.5-65.8$ & ND-3.2 & $0.8-2.3$ & $0.5-0.8$ \\
\hline $\begin{array}{l}\text { Vallisneria ameri- } \\
\text { cana Michx. }\end{array}$ & L & 2 & $\mathrm{ND}-0.4$ & $0.2-0.4$ & ND & ND & $1.3-2.0$ & 0.6 \\
\hline \multicolumn{9}{|c|}{ SPECIES TERRESTRIAL OR WITH FLOATING OR EMERGENT LEAVES ${ }^{c}$} \\
\hline $\begin{array}{c}\text { Alisma plantago- } \\
\text { aquatica } \mathrm{L} .\end{array}$ & $\mathrm{L}$ & 1 & ND & 0.8 & ND & ND & 0.9 & 0.2 \\
\hline Juncus sp. & $\mathrm{L}$ & 1 & ND & 0.1 & ND & ND & 0.3 & 0.1 \\
\hline J. nodosus L. & $\mathbf{L}$ & 1 & ND & 0.1 & ND & ND & ND & 0.1 \\
\hline $\begin{array}{l}\text { Lythrum salicaria } \\
\text { L. }\end{array}$ & $\mathrm{L}$ & 1 & ND & 0.1 & ND & ND & 0.2 & 0.1 \\
\hline $\begin{array}{l}\text { Phragmites aus- } \\
\text { tralis (Cav.) } \\
\text { Steud. }\end{array}$ & $\mathbf{L}+\mathbf{S}$ & 1 & ND & 0.1 & ND & ND & ND & 0.1 \\
\hline $\begin{array}{l}\text { Polygonum lapa- } \\
\text { thifollum } \mathrm{L} .\end{array}$ & $\mathrm{L}$ & 1 & ND & 0.3 & ND & ND & ND & 0.2 \\
\hline$P$. natans Eaton & $\mathrm{L}+\mathrm{S}$ & 1 & ND & 0.1 & ND & 4.5 & ND & 0.1 \\
\hline $\begin{array}{l}\text { Rumex maritimus } \\
\mathrm{L} .\end{array}$ & $\mathrm{L}+\mathrm{S}$ & 1 & ND & 0.1 & 40.3 & ND & ND & 0.2 \\
\hline $\begin{array}{l}\text { Sagitaria latifolia } \\
\text { Willd. }\end{array}$ & $\mathrm{L}$ & 1 & ND & 0.2 & ND & ND & ND & 0.1 \\
\hline $\begin{array}{l}\text { Salix amygda- } \\
\text { loides Anderss. }\end{array}$ & $L$ & 1 & ND & 3.0 & ND & ND & 3.0 & 0.8 \\
\hline S. fragilis $\mathbf{L}$. & L & 1 & ND & 8.0 & ND & ND & 0.2 & $\begin{array}{l}0.4 \\
0\end{array}$ \\
\hline $\begin{array}{l}\text { Scirpus acutus } \\
\text { Muhl. }\end{array}$ & $\mathbf{L}$ & 3 & ND-56.3 & $0.1-0.2$ & ND & ND-2.9 & $\mathrm{ND}-0.2$ & ND -0.1 \\
\hline $\begin{array}{l}\text { S. americanus } \\
\text { Pers. }\end{array}$ & $\mathbf{L}$ & 8 & ND-1.4 & $\mathrm{ND}-0.3$ & ND & ND-7.4 & $\mathrm{ND}-0.6$ & $\mathrm{ND}-0.1$ \\
\hline S. validus Vahl.? & $\mathbf{L}$ & 2 & $0.3-66.9$ & ND-0.4 & ND & ND & ND & 0.1 \\
\hline $\begin{array}{l}\text { Typha angustifo- } \\
\text { lia } \mathrm{L} .\end{array}$ & L & 10 & ND-39.2 & ND -4.8 & ND-18.0 & ND-5.3 & $\mathrm{ND}-0.5$ & $\mathrm{ND}-0.2$ \\
\hline & R & 5 & ND -0.2 & $\begin{array}{r}\text { ND }-0.3 \\
0.3-0.8\end{array}$ & ND & ND & $\mathrm{ND}-0.2$ & $\begin{array}{c}0.1 \\
0.1\end{array}$ \\
\hline T. angustifolia $\mathrm{L}$. & Fr & 6 & ND-14.4 & ND -0.3 & $\begin{array}{l}\text { ND } \\
\text { ND }\end{array}$ & $\begin{array}{l}\text { ND } \\
\text { ND }\end{array}$ & $\begin{array}{c}\text { ND } \\
\text { ND-0.7 }\end{array}$ & $\begin{array}{l}N D-0.1 \\
0.1-0.6\end{array}$ \\
\hline \multicolumn{9}{|c|}{ 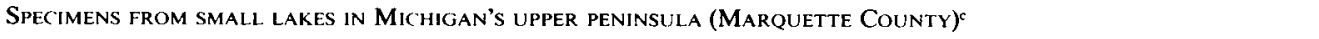 } \\
\hline $\begin{array}{l}\text { Myriophyllum ex- } \\
\text { albescens Fern. }\end{array}$ & $\mathbf{L}+\mathbf{S}$ & 1 & ND & 1.0 & 168.6 & ND & 2.2 & 0.5 \\
\hline $\begin{array}{l}\text { Nymphaea odora- } \\
\text { ta Alton }\end{array}$ & $\mathbf{L}$ & 1 & ND & 0.2 & ND & ND & 0.8 & 0.1 \\
\hline $\begin{array}{l}\text { Pontederia corda- } \\
\text { ta } \mathrm{L} \text {. }\end{array}$ & $\mathbf{L}$ & 1 & 0.1 & 0.04 & ND & 5.4 & ND & 0.04 \\
\hline $\begin{array}{l}\text { Potamogeton rich- } \\
\text { ardsonii (Benn.) } \\
\text { Rydb. }\end{array}$ & $\mathbf{L}+\mathbf{S}$ & 1 & ND & 0.3 & 84.7 & 2.3 & 2.8 & 0.3 \\
\hline $\begin{array}{l}\text { Scirpus acutus } \\
\text { Muhl. }\end{array}$ & $\mathbf{L}$ & 1 & ND & 0.1 & 255.6 & ND & ND & 0.04 \\
\hline Typha latifolia $\mathrm{L}$. & L & 1 & 0.1 & 0.05 & ND & ND & ND & 0.1 \\
\hline $\begin{array}{l}\text { Vallisneria ameri- } \\
\text { cana Michx. }\end{array}$ & $\mathrm{L}$ & 1 & 0.2 & 0.3 & 67.6 & ND & ND & 0.3 \\
\hline
\end{tabular}

a Sensitivity limits (ppm;: $\mathrm{Co}, \mathrm{Cs}, 0.03 ; \mathrm{Sb}, \mathrm{Th}, 0.05 ; \mathrm{Ag}, \mathrm{As}, \mathrm{Ce}, \mathrm{U}, 0.1 ; \mathrm{Hg}, \mathrm{Se}, 0.2 ; \mathrm{Cd}, \mathrm{Cr}, \mathrm{Rb}, \mathrm{Zn}, 0.5 ; \mathrm{Ni}, 6.0$; $\mathrm{Ba}, 10.0$.

"ND indicates "not detected" in sample or in at least one of several samples.

- $\mathrm{L}=$ leaf, $\mathrm{S}=$ stem, $\mathrm{Fr}=$ fruit, $\mathrm{Fl}=$ flowers, $\mathrm{R}=$ rhizome, $\mathrm{Wp}=$ whole plant.

Where multiple samples were analyzed, the ranges of values are listed. 
TABLE 2. Extended

\begin{tabular}{|c|c|c|c|c|c|c|c|c|}
\hline cr & (s & $\mathrm{Ni}$ & $\mathrm{Rb}$ & $\mathrm{Sb}$ & $\mathrm{Se}$ & Th & $\mathrm{U}$ & $\mathrm{Zn}$ \\
\hline 0.1 & ND & ND & ND & ND & ND & ND & ND & 3.8 \\
\hline $\begin{array}{c}4.0-18.1 \\
3.5\end{array}$ & $\begin{array}{c}0.4-0.9 \\
\text { ND }\end{array}$ & $\begin{array}{c}\text { ND-1 } 3.2 \\
25.3\end{array}$ & $\begin{array}{c}32.6-45.5 \\
2.6\end{array}$ & $\begin{array}{c}0.1-0.3 \\
\text { ND }\end{array}$ & $\begin{array}{c}1.1-2.7 \\
0.6\end{array}$ & $\begin{array}{c}0.8-1.7 \\
\text { ND }\end{array}$ & $\begin{array}{c}\text { ND }-0.4 \\
\text { ND }\end{array}$ & $\begin{array}{c}39.6-159.9 \\
47.0\end{array}$ \\
\hline $2.5-5.5$ & 0.7 & ND & 7.1 & ND-0.1 & $0.6-1.3$ & 0.7 & ND-0.4 & $22.2-63.0$ \\
\hline $\begin{array}{l}1.3-3.9 \\
3.3-6.9\end{array}$ & $\begin{array}{r}\text { ND }-0.9 \\
0.3-0.9\end{array}$ & $\begin{array}{c}\text { ND-23.8 } \\
\text { ND }\end{array}$ & $\begin{array}{l}6.6-12.8 \\
7.4-10.6\end{array}$ & $\begin{array}{r}\text { ND }-0.5 \\
0.2-0.3\end{array}$ & $\begin{array}{r}0.3-1.5 \\
\text { ND-1.2 }\end{array}$ & $\begin{array}{r}\text { ND }-0.3 \\
0.3-0.8\end{array}$ & $\begin{array}{l}\text { ND-0.6 } \\
\text { ND-1.1 }\end{array}$ & $\begin{array}{l}21.5-47.7 \\
23.9-458.3\end{array}$ \\
\hline $\begin{array}{c}2.2-7.7 \\
6.3\end{array}$ & $\begin{array}{c}\mathrm{ND}-0.3 \\
0.2\end{array}$ & $\begin{array}{l}\text { ND } \\
\text { ND }\end{array}$ & $\begin{array}{l}\text { ND } \\
9.3\end{array}$ & $\begin{array}{c}\text { ND }-0.3 \\
0.1\end{array}$ & $\begin{array}{l}\text { ND } \\
0.5\end{array}$ & $\begin{array}{l}\text { ND } \\
0.5\end{array}$ & $\begin{array}{l}\text { ND } \\
\text { ND }\end{array}$ & $\begin{array}{c}36.8-108.0 \\
39.5\end{array}$ \\
\hline $3.3-4.4$ & ND- 0.3 & ND-7.6 & $3.8-7.9$ & $0.1-0.4$ & $\mathrm{ND}-0.5$ & $\mathrm{ND}-0.4$ & $\mathrm{ND}-0.9$ & $24.9-35.4$ \\
\hline 2.9 & 0.1 & $6.6-11.8$ & $3.3-7.6$ & 0.1 & $0.4-0.7$ & ND & $0.5-0.9$ & $19.8-31.5$ \\
\hline 1.0 & 0.6 & ND & 36.2 & ND & ND & ND & ND & 80.5 \\
\hline 0.8 & 0.6 & ND & 75.8 & ND & 0.5 & ND & ND & 64.2 \\
\hline 1.2 & ND & ND & 19.5 & ND & ND & ND & ND & 35.6 \\
\hline 0.5 & 0.1 & ND & 6.8 & ND & ND & ND & ND & 109.4 \\
\hline 0.8 & 0.3 & ND & 8.4 & ND & ND & ND & ND & 17.0 \\
\hline ND & 0.2 & 3.3 & 40.8 & ND & ND & ND & ND & 44.4 \\
\hline 1.5 & 0.04 & ND & 12.1 & ND & ND & ND & ND & 22.6 \\
\hline 1.0 & 0.1 & ND & 40.8 & ND & ND & 0.1 & ND & 44.4 \\
\hline 2.1 & ND & ND & 46.6 & ND & ND & ND & ND & 33.1 \\
\hline 4.1 & 0.4 & ND & 11.8 & 0.3 & 1.6 & 0.5 & ND & 39.4 \\
\hline $\begin{array}{c}0.4 \\
\mathrm{ND}-0.8\end{array}$ & $\begin{array}{c}\text { ND } \\
\text { ND-7.7 }\end{array}$ & $\begin{array}{r}7.2 \\
\text { ND }\end{array}$ & $\begin{array}{c}7.1 \\
1.6-3.2\end{array}$ & $\begin{array}{l}0.03 \\
\text { ND }\end{array}$ & $\begin{array}{c}\text { ND } \\
\text { ND-0.3 }\end{array}$ & $\begin{array}{l}\text { ND } \\
\text { ND }\end{array}$ & $\begin{array}{l}\text { ND } \\
\text { ND }\end{array}$ & $\begin{array}{c}158.5 \\
19.1-28.8\end{array}$ \\
\hline ND-2.2 & ND -0.1 & ND & $2.7-27.0$ & $\mathrm{ND}-0.2$ & ND & $\mathrm{ND}-0.1$ & ND & $10.3-37.0$ \\
\hline $0.3-1.5$ & ND-1.1 & ND-144.3 & $4.5-14.4$ & ND & ND- -0.9 & ND & ND & $28.4-37.0$ \\
\hline $0.6-3.6$ & ND -5.9 & ND-50.6 & $\mathrm{ND}-4.1$ & ND & ND & ND & ND & $13.9-39.1$ \\
\hline $0.3-1.7$ & ND & ND-17.6 & $1.5-6.5$ & ND & ND & ND & ND & $7.9-33.9$ \\
\hline $2.1-9.0$ & ND & ND-5.2 & $4.9-9.0$ & ND-0.4 & ND & ND & ND & $27.4-42.7$ \\
\hline $2.6-45.2$ & ND & $N D-22.1$ & $0.7-11.2$ & ND & ND & ND-0.1 & ND & $24.2-44.1$ \\
\hline 1.6 & ND & ND & 1.7 & 0.1 & ND & ND & 1.1 & 29.6 \\
\hline 0.7 & 0.04 & 3.3 & 6.6 & ND & ND & ND & ND & 25.0 \\
\hline 0.8 & ND & ND & 1.1 & ND & ND & ND & ND & 14.5 \\
\hline 1.1 & ND & ND & 10.4 & ND & 0.5 & ND & 0.5 & 45.1 \\
\hline 1.2 & ND & ND & 7.2 & 0.02 & ND & ND & ND & 11.0 \\
\hline 1.2 & ND & ND & 1.8 & 0.1 & ND & ND & 0.8 & 21.7 \\
\hline 2.5 & ND & ND & 2.3 & 0.1 & ND & ND & 0.6 & 26.3 \\
\hline
\end{tabular}




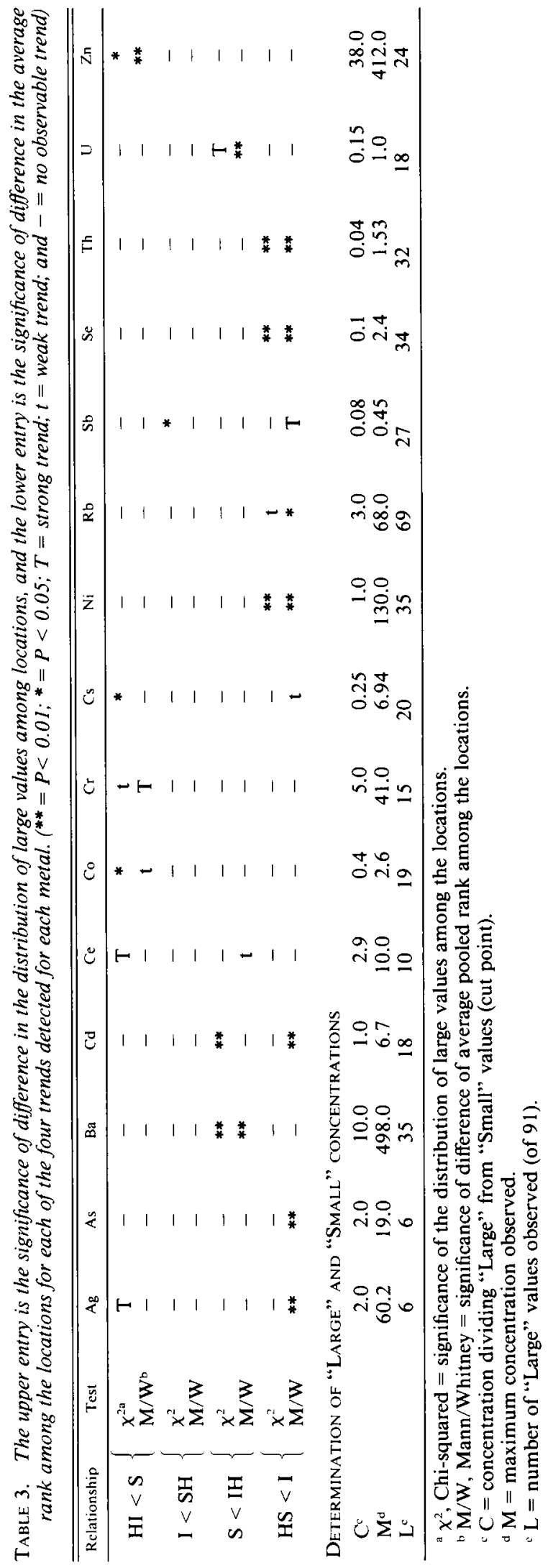


$C d$. The placement of $\mathrm{H}$, although of great interest scientifically, can be done by insignificant trends at best, because of the small number (6) of samples from $\mathrm{H}$. The distributions of $\mathrm{Cd}$, with a somewhat more gradual and continuous rise in concentration with number of rank-ordered samples, was cut, and 18 "high" values turned out to be recognized. Roughly $21 \%$ of the pooled sample is in the "high" category with $21 \%$ of $S$ and $33 \%$ of $\mathrm{H}$ "high"; but $87 \%$ of $\mathrm{I}$ is "high," and this is what generates the significance. $\mathrm{H}$ is intermediate, but closer to $\mathrm{S}$ in trend. The average rank orders in $\mathrm{H}$ are also intermediate, but closer to I in trend.

$\mathrm{Ce} . \mathrm{Ce}$ is basically the same as $\mathrm{Ag}$, but the competing trends are not so strong. The weak, but observable, insignificant trend in ranks (Table 2) is in the opposite direction from the perfect small sample trend in extreme values. All 10 very large values are in $S$, as are most of the samples in which Ce was not even detectable.

Cs. Cs behaved like $\mathrm{Ag}$, but with the strength of the trends reversed. The 20 "large" values are all in $S$; yet, all the values below the median are in $S$ as well, leaving the I values in the middle.

$S b$. The distribution of values for $\mathrm{Sb}$ rises gradually. The distribution was cut somewhat arbitrarily, and 27 large values were recognized. The maximum is only about seven times greater than the cut point, while in the others, the maximum is often 20 or more times greater than the value of the cut point. These 27 largest values all come from $\mathrm{S}$ and $\mathrm{H}$, but the next 12 are all from I, generating a higher average rank order with a realized significance of 0.0625 .

Almost all of the Island samples were taken from the inland pond. When the data from the Island shoreline sample of Chara were removed from the rest of the Island samples and placed in its own class, unpredictable differences in comparisons were observed. With some metals, such as $\mathrm{Ce}$ and $\mathrm{Co}$, the island Chara resembled other plants on the island, while with other metals such as $\mathrm{Ag}, \mathrm{Rb}$, and somewhat for $\mathrm{Cd}, \mathrm{Ce}$, and $\mathrm{Co}$, its levels were closer to those found on the shore of the bay. Chara cannot be classified as Island-like or shore-like, because some of the metals follow the island trend and some follow the shoreline trend. To complicate it further, some of the metal concentrations in Chara lie above or below all other values. Thus, the shoreline of the island seems to be a case separate from the bay shoreline, and, from the isolated pond on Charity Island.

DisCUSSION AND SUMMARY-Significant trends were encountered in 13 of 15 metals, of which 9 metals (Ag, As, Ba, Cd, Ni, Rb, Se, Th, U) have significantly higher concentrations in the Island plants than in the plants along the shoreline of the bay (see Tables 1 and 2). These results suggest specific concentrating mechanisms.

Higher values from the shoreline of Saginaw Bay were observed for $\mathrm{Co}, \mathrm{Cs}, \mathrm{Sb}$, and $\mathrm{Zn}$; but the shoreline samples also had most of the "not detectable" values. The Island samples were detectable and clumped just below the "high" values from the shoreline. This lower variance in concentration values perhaps suggests a more steady deposition and stable sediments in the pond, as compared with the washing and battering by heavy weather along the open shoreline.

Other factors may affect the accumulation of these heavy metals by aquatic macrophytes. At season's end, the perennial plants die back and release their accumulated metals, which can then settle out of the water and onto the sediments. The heavy metals are adsorbed by the organic material in the sediments. This organic material is suspended in the water until it settles. In this way, plants tend to keep the heavy metals on site in the sediment. Currents and wave action affect the deposition of sediment on the shore by continually resuspending the organic matter, so that the largest rates of deposition of sediment are not on the shoreline, where the plants grow, but are in the deeper parts in the center of Saginaw Bay (Robbins, 1981; Kemp and Thomas, 1976). Currents also affect this deposition by forming sediment bars. These bars grow until they break the surface of the water and become islands. The plants growing on a given island are not only accumulating the heavy metals from the water, but are also accumulating the heavy metals from the top sediments. These sediments, deposited in the last 30 years, have higher concentrations of heavy metals due to the increase in pollution in the area. This could explain the higher levels of heavy metals found in plants on Charity Island as compared to those along the shore of Saginaw Bay. However, Dorr and Eschman (1970) make it clear that Charity Island is a limestone outcrop. This does not explain the higher concentrations of metals on the bay's shore. Since some of the samples taken from the Island pond had the same or higher con- 
centrations as the bay shoreline, the distance of Charity Island from bay shore pollution sources suggests that these high concentrations are due to metals released by erosion of the bedrock, or to metals arriving from the air; perhaps mechanisms exist to transport and concentrate metals in the island shore sediments, which could be washed into the pond during violent storms. Measurements of metal concentrations in the sediments and in the air, as well as information about the amounts of metals released yearly into Saginaw Bay over the past several years, would be useful for testing these possible explanations. Rygwelski (1984), and Rygwelski et al. (1984) have studied sedimentation of metals in Saginaw Bay, and Richardson et al. (1983) have studied transport of PCB's in Saginaw Bay, but none of these works test specific hypotheses to explain differential spatial deposition of metals.

The location of Charity Island offers a more moderate climate than the shoreline of the bay. The bay surrounds Charity Island, keeping it cooler in the spring, and warmer than the mainland, well into the fall. The growth level of aquatic macrophytes achieved by summer (our sampling time) is also an important factor that determines, in part, the capability and efficiency of these plants as sinks for heavy metals.

Folsom (1984) has demonstrated metal concentration effects on the amount of metal taken up by plants. Thus, plant population density could also affect the data, in that a stand of high density may pick up an equal amount of metal per square meter, but plants in the high density stand will have lower metal content in ppm. The Island plant stand densities, although not measured, were visibly less dense than those along the Saginaw Bay shore.

The ratio of good heavy metal accumulators to all heavy metal accumulators was about the same on Charity Island and along the Saginaw Bay shore; at both sites, approximately $25 \%$ of the species sampled were good heavy metal accumulators (Wells et al., 1981). Variation in species growing at the sampling sites can be caused by the amounts of heavy metals in their environment. High levels of metal may eliminate a species from an area. The trends observed could be due to an elimination of the more susceptible species, with poor accumu- lators but good tolerators more numerous on the Saginaw Bay shore.

An understanding of heavy metal accumulation by aquatic macrophytes will contribute to an understanding of the spatial dynamics of heavy metal distribution, which in turn may enable us to more effectively control this dangerous class of pollutants, without unnecessarily reducing the efficiency of our industrial activities.

\section{LITERATURE CITED}

Box, G. E. P. 1949. A general distribution theory for a class of likelihood criteria. Biometrika 36: 317-346.

Conover, W. J. 1971. Practical nonparametric statistics. John Wiley \& Sons, New York.

DorR, J. A., AND D. E. Eschman. 1970. Geology of Michigan. University of Michigan Press, Ann Arbor, p. 398.

FOLSOM, B. L., JR. 1984. WES plant bioassay procedure. U.S. Army Corps of Engineers, Information Exchange Bull., Vol. D-84-3, pp. 2-4.

KemP, A. L. W., AND R. L. THOMAS. 1976. Impact of man's activities on the sediments of Lakes Ontario, Erie, and Huron. Water, Air, Soil Pollut. 5: 469-490.

ManN, H. B., AND D. R. Whitney. 1947. On a test of whether one of two random variables is stochastically larger than the other. Ann. Math. Stat. 18: 50-60.

Richardson, W. L., V. E. Smith, AND R. Wethington. 1983. Dynamic mass balance of $P C B$ and suspended solids in Saginaw Bay - a case study. In D. Macay, $\mathrm{S}$. Paterson, S. J. Eisenreich, and M. S. Simmons [eds.], Physical behavior of PCB's in the Great Lakes. Ann Arbor Science, Ann Arbor, Mich.

Robins, J. A. 1981. Sediments of Saginaw Bay, Lake Huron: elemental composition and accumulation rates. U.S. EPA Report. Mimeo.

RYGWELSKI, K. R. 1984. Partitioning of toxic trace metals between solid and liquid phases in the Great Lakes. In J. O. Nriagu and M. S. Simmons [eds.], Contaminants in the Great Lakes. John Wiley \& Sons, New York.

—_ J. M. Townsend, And V. E. Smith. 1984. Partioning of cadmium, copper, lead, and zinc among particulate fractions and water in Saginaw Bay (Lake Huron). Environmental Protection Agency, 600/S384-069.

SOKAL, R. R., ANd F. J. Rohlf, 1967. Biometry. W. H. Freeman, San Francisco.

Wells, J. R., P. B. Kaufman, and J. D. Jones. 1980. Heavy metal contents in some macrophytes from Saginaw Bay (Lake Huron, U.S.A.). Aq. Bot. 9: 185-193.

$\longrightarrow, \longrightarrow,-$ G. F. EstabroOK, AND N. S. GHosheH. 1981. Contents of some heavy metals in plants from Saginaw Bay (Lake Huron) and some small lakes in wilderness areas of Michigan's upper peninsula as analyzed by neutron activation analysis. $\mathrm{J}$. Radioanal. Chem. 71(1-2): 97-113. 